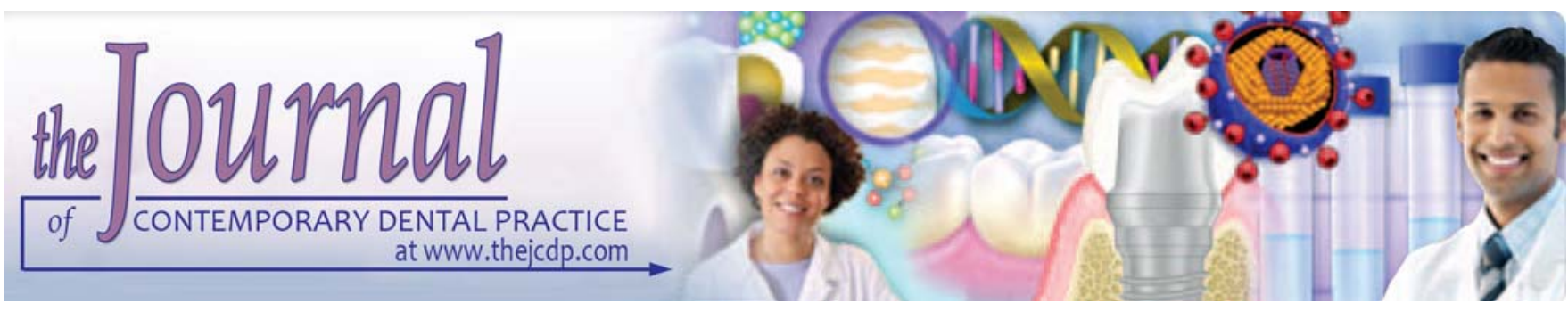

\title{
Antimicrobial Efficacy of Octenidine Hydrochloride, MTAD and Chlorhexidine Gluconate Mixed with Calcium Hydroxide
}

Resmiye Ebru Tirali, Kamran Gulsahi, Sevi Burcak Cehreli, Zeynep Ceren Karahan, Emel Uzunoğlu, Atilla Elhan

\begin{abstract}
Objective: The aim of this in vitro study was to investigate whether mixing with calcium hydroxide $\left[\mathrm{Ca}(\mathrm{OH})_{2}\right]$ affects the antimicrobial action of Octenidine hydrochloride (Octenisept), MTAD and chlorhexidine against Enterococcus faecalis and Candida albicans.

Materials and methods: Freshly grown cultures of Enterococcus faecalis, Candida albicans and a mixture of both strains were incubated in agar plates containing brain-heart infusion broth (BHIB). Zones of inhibition were measured at 24 and 48 hours. Statistical analysis was performed using Mann-Whitney $U$ test and Kruskal-Wallis one-way analysis of variance (ANOVA, both $p=0.05)$.
\end{abstract}

Results: Mixing with $\mathrm{Ca}(\mathrm{OH})_{2}$ significantly increased the antibacterial effect of Octenisept $(p<0.05)$, but did not alter its antifungal activity. Only chlorhexidine showed more antibacterial and antifungal efficiency compared to its $\mathrm{Ca}(\mathrm{OH})_{2}$-mixed version (both $\mathrm{p}<0.05$ ). Mixing with $\mathrm{Ca}(\mathrm{OH})_{2}$ decreased the antibacterial efficacy of MTAD, but increased its antifungal effect (both $\mathrm{p}<0.05)$.

Conclusion: These results demonstrate the differential effects of $\mathrm{Ca}(\mathrm{OH})_{2}$ addition on the antimicrobial action of the tested endodontic medicaments in vitro. $\mathrm{Ca}(\mathrm{OH})_{2}$ was as effective as its combination with all of the tested medicaments.

Keywords: C. albicans, Chlorhexidine, E. faecalis, MTAD, Octenisept.

How to cite this article: Tirali RE, Gulsahi $K$, Cehreli SB, Karahan ZC, Uzunoğlu E, Elhan A. Antimicrobial Efficacy of Octenidine Hydrochloride, MTAD and Chlorhexidine Gluconate Mixed with Calcium Hydroxide. J Contemp Dent Pract 2013;14(3):456-460.

Source of support: Nil

Conflict of interest: None declared

\section{INTRODUCTION}

The primary goal of endodontic therapy is to eliminate microorganisms and their byproducts from the root canal system. Root canal asepsis is attempted by means of mechanical instrumentation and chemical irrigation, ${ }^{1}$ but these procedures do not completely eliminate bacteria in the lateral and accessory root canals and apical deltas. ${ }^{2}$ Particularly resistant species such as Enterococcus faecalis and Candida albicans may persist within the root canal system, and sustain the presence of apical periodontitis. ${ }^{3,4}$ Thus, placement of an interappointment intracanal medicament has been recommended to further reduce bacteria in the root canal system. ${ }^{5,6}$

Chlorhexidine (CHX) gluconate has been suggested as an endodontic irrigant and intracanal medication by virtue of its wide antimicrobial spectrum, ability to maintain its antibacterial action for a prolonged duration when adhered to anionic substrates, slow release at low concentrations, lower cytotoxicity than sodium hypochlorite, and its efficient clinical performance. ${ }^{7,8}$

Octenidine hydrochloride, (N,N'-(1,10-decanediyldi1(4H)-pyridinyl-4 ylidine) bis-[1-octanamine] dihydrochloride), a new bipyridine antimicrobial compound, has been developed as a potential antimicrobial/antiplaque agent for use in mouthwash formulations. ${ }^{9,10}$ Octenidine hydrochloride appears to be more effective than CHX by means of prolonged antiadhesive activity on bacteria. ${ }^{11}$ Octenidine hydrochloride has been suggested as an alternative endodontic irrigant based on its antimicrobial effects and low cytotoxicity. ${ }^{4}$

BioPure MTAD (Tulsa Dentsply, Tulsa, OK), is a mixture of doxycycline, Tween-80, and citric acid. Doxycycline and citric acid exhibit antimicrobial and acid etching properties, rendering MTAD as a promising antimicrobial against Enterococcus faecalis, and as a smear layer removal agent. ${ }^{12}$ Calcium hydroxide $\left[\mathrm{Ca}(\mathrm{OH})_{2}\right]$ is one of the most versatile medications in dentistry, especially 
for its use as an intracanal disinfectant in endodontic treatment. ${ }^{13}$ Several researchers have studied the associations of $\mathrm{Ca}(\mathrm{OH})_{2}$ with different vehicles and antimicrobial substances, such as antibiotics, ${ }^{14} \mathrm{CHX},{ }^{15}$ camphorated paramonochorophenol $^{16}$ and glycerin. ${ }^{17}$

In light of these observations, the purpose of this in vitro study was to investigate and compare the antibacterial and antifungal activity of Octenisept, MTAD and CHX, alone or when mixed with $\mathrm{Ca}(\mathrm{OH})_{2}$. The null hypothesis tested was that, addition of $\mathrm{Ca}(\mathrm{OH})_{2}$ would significantly increase the antimicrobial effect of the tested endodontic medicaments.

\section{MATERIALS AND METHODS}

The medicaments tested in this study were: $0.1 \%$ octenidine hydrochloride (Octenisept, Schülke and Mayr GmBH, Norderstedt, Germany), MTAD (BioPure MTAD, Dentsply, Tulsa Dental, Tulsa, OK) and 2\% CHX gluconate (Sigma, St. Louis, MO). Sterile saline solution served as a negative control. In approximation to common clinical practice, combinations of the medicaments with $\mathrm{Ca}(\mathrm{OH})_{2}$ were prepared by mixing each solution with $\mathrm{Ca}(\mathrm{OH})_{2}$ powder (Sultan Healthcare Inc, Englewood, NJ) to form a slurry at a ratio of $1.5: 1$ (vol/wt). ${ }^{17}$ Freshly prepared pastes were used for each test.

\section{Radial Diffusion Test}

The test was performed as described by Lee et al ${ }^{18}$ with some modifications. Briefly, Enterococcus faecalis (ATCC 29212) and Candida albicans (ATCC 10231) strains were cultured in brain-heart infusion broth (BHIB) for 24 hours. Agar plates were prepared by adding each organism to sterilized brain-heart infusion agars (BHIA) at $40^{\circ} \mathrm{C}$, so that each agar would contain $10^{6} \mathrm{CFU} / \mathrm{ml}$ of Enterococcus faecalis or $10^{6} \mathrm{CFU} / \mathrm{ml}$ of Candida albicans, or a mixture of Enterococcus faecalis and Candida albicans (each $10^{3}$ $\mathrm{CFU} / \mathrm{ml})$. The agars containing the microorganisms were poured into $8 \times 8 \mathrm{~cm}^{2}$ petri dishes to obtain a thickness of $3 \mathrm{~mm}$. Following solidification of the agars, 5 to 6 wells with $3 \mathrm{~mm}$ diameter were opened. These wells were filled with the test medicaments or sterile distilled water (as negative control), and incubated at $37^{\circ} \mathrm{C}$ for 3 hours.
Thereafter, the plates were overlaid with sterile BHIA, and incubated at $37^{\circ} \mathrm{C}$ for 48 hours. Zone diameters were measured at 24th and 48th hours. The zone diameters observed at 48 hours were the same with those observed at 24 hours, but were more distinctive.

\section{Statistical Analysis}

Comparison of inhibition zones among the microorganisms were assessed by the Mann-Whitney U test. Statistical differences among the test medicaments and their combination with $\mathrm{Ca}(\mathrm{OH})_{2}$ were assessed by Kruskal-Wallis one-way analysis of variance (ANOVA). When the p-value from the Kruskal-Wallis test was statistically significant ( $p<0.05$ ), the multiple comparison test was used to determine the test groups that differed from others.

\section{RESULTS}

As expected, the negative control (saline) was ineffective against all tested microorganisms. Mixing with $\mathrm{Ca}(\mathrm{OH})_{2}$ significantly increased the antimicrobial efficiency of Octenisept on Enterococcus faecalis and Enterococcus faecalis + Candida albicans (Mann-Whitney U test, p < 0.05), but its effect on Candida albicans was not statistically significant ( $\mathrm{p}>0.05$, Table 1 ). Mixing with $\mathrm{Ca}(\mathrm{OH})_{2}$ significantly decreased the efficiency of MTAD against Enterococcus faecalis and Enterococcus faecalis + Candida albicans (Mann-Whitney U test, $\mathrm{p}<0.05$, Table 2). When used alone, MTAD did not show any antifungal effect, while its combination with $\mathrm{Ca}(\mathrm{OH})_{2}$ significantly increased the inhibition zones on Candida albicans ( $<<0.05$, Table 2). In contrast to other test medicaments, the use of CHX alone yielded a higher antibacterial and antifungal efficiency than its combined version with $\mathrm{Ca}(\mathrm{OH})_{2}$ ( $\mathrm{p}<0.05$, Table 3 ). Finally, the antibacterial and antifungal effect of $\mathrm{Ca}(\mathrm{OH})_{2}$ was similar to that achieved by its mixture with the tested antimicrobial agents ( $>0.05$, Table 3$)$.

\section{DISCUSSION}

Chemomechanical cleaning and shaping of the root canal effectively reduces microbial numbers, but alone cannot accomplish disinfection of the entire root canal system. ${ }^{19}$ Residual root canal infection may then sustain persistent or

Table 1: Inhibition zones (in $\mathrm{mm}$ ) of octenisept and octenisept $+\mathrm{Ca}(\mathrm{OH})_{2}$ on $E$. faecalis, C. albicans and E. faecalis + C. albicans

\begin{tabular}{|c|c|c|c|c|c|}
\hline \multirow[t]{2}{*}{ Microorganism } & \multicolumn{2}{|c|}{ OCT } & \multicolumn{2}{|c|}{$\mathrm{OCT}+\mathrm{Ca}(\mathrm{OH})_{2}$} & \multirow{2}{*}{$\begin{array}{c}p \text {-value } \\
(\text { Mann-Whitney } \cup \text { test })\end{array}$} \\
\hline & $X \pm S D$ & $\begin{array}{l}\text { Median } \\
(\text { min-max) }\end{array}$ & $X \pm S D$ & $\begin{array}{l}\text { Median } \\
(\text { min-max) }\end{array}$ & \\
\hline E. faecalis & $8.67 \pm 0.52$ & $9(8-9)$ & $15.67 \pm 0.52$ & $16(15-16)$ & 0.002 \\
\hline C. albicans & $14.67 \pm 1.86$ & $14(13-17)$ & $15.67 \pm 0.52$ & $16(15-16)$ & 0.39 \\
\hline E. faecalis + C. albicans & $9.67 \pm 0.52$ & $10(9-10)$ & $15.67 \pm 1.37$ & $16(14-17)$ & 0.002 \\
\hline
\end{tabular}

SD: Standard deviation; OCT: Octenisept 
Table 2: Inhibition zones (in $\mathrm{mm}$ ) of MTAD and MTAD $+\mathrm{Ca}(\mathrm{OH})_{2}$ on $E$. faecalis, C. albicans and $E$. faecalis + C. albicans

\begin{tabular}{|c|c|c|c|c|c|}
\hline \multirow[t]{2}{*}{ Microorganism } & \multicolumn{2}{|c|}{ MTAD } & \multicolumn{2}{|c|}{$\mathrm{MTAD}+\mathrm{Ca}(\mathrm{OH})_{2}$} & \multirow{2}{*}{$\begin{array}{c}p \text {-value } \\
\text { (Mann-Whitney } U \text { test) }\end{array}$} \\
\hline & $X \pm S D$ & $\begin{array}{l}\text { Median } \\
\text { (min-max) }\end{array}$ & $X \pm S D$ & $\begin{array}{l}\text { Median } \\
\text { (min-max) }\end{array}$ & \\
\hline E. faecalis & $30.00 \pm 0.89$ & $30(29-31)$ & $16.33 \pm 1.37$ & $16(15-18)$ & 0.002 \\
\hline C. albicans & $0.00 \pm 0.00$ & $0(0-0)$ & $16.33 \pm 5.16$ & $16(16-17)$ & 0.002 \\
\hline E. faecalis + C. albicans & $0.00 \pm 0.00$ & $0(0-0)$ & $15.67 \pm 5.16$ & $(16(15-16)$ & 0.002 \\
\hline
\end{tabular}

SD: Standard deviation

\begin{tabular}{|c|c|c|c|c|c|}
\hline \multirow[t]{2}{*}{ Microorganism } & \multicolumn{2}{|c|}{$\mathrm{CHX}$} & \multicolumn{2}{|c|}{$\mathrm{CHX}+\mathrm{Ca}(\mathrm{OH})_{2}$} & \multirow{2}{*}{$\begin{array}{c}p \text {-value } \\
\text { (Mann-Whitney } \cup \text { test) }\end{array}$} \\
\hline & $X \pm S D$ & $\begin{array}{l}\text { Median } \\
\text { (min-max) }\end{array}$ & $X \pm S D$ & $\begin{array}{l}\text { Median } \\
(\text { min-max) }\end{array}$ & \\
\hline E. faecalis & $19.00 \pm 0.89$ & $19(18-20)$ & $16.33 \pm 0.52$ & $16(16-17)$ & 0.002 \\
\hline C. albicans & $21.67 \pm 0.51$ & $22(21-22)$ & $15.67 \pm 0.52$ & $16(15-16)$ & 0.002 \\
\hline E. faecalis + C. albicans & $20.33 \pm 1.30$ & $20(19-22)$ & $17.33 \pm 1.37$ & $17(16-19)$ & 0.009 \\
\hline
\end{tabular}

SD: Standard deviation; CHX: Chlorhexidine

recurrent periapical disease. ${ }^{5,6,19,20}$ Within an infected root canal, bacteria grow by forming biofilm colonies in conditions where the availability of carbohydrates is limited. ${ }^{21}$ Microorganisms that are members of a biofilm community can be up to 1,000 times more resistant to antimicrobial agents than their planktonic counterparts, 22 which may jeopardize the success of endodontic irrigants and medicaments. ${ }^{23}$ These observations justify the present attempt to evaluate the possible contributory effect of $\left[\mathrm{Ca}(\mathrm{OH})_{2}\right]$ on the antimicrobial efficacy of the tested endodontic medicaments.

Enterococcus faecalis and Candida albicans are considered to be the most resistant species in the infected root canals, and are often associated with endodontic treatment failures. ${ }^{20}$ Both microorganisms have been used in many studies to test the efficacy of endodontic medicaments and irrigants, owing to their high resistance to antibacterial substances. ${ }^{24,25}$ Consequently, this investigation utilized Enterococcus faecalis and Candida albicans as test microorganisms against which antibacterial action of different endodontic medicaments was investigated using a radial diffusion test.

Results of the present study showed that mixing with $\mathrm{Ca}(\mathrm{OH})_{2}$ significantly increased the antibacterial effect of Octenisept, but did not alter its antifungal activity. Comparisons cannot be made due to the lack of previously published data. However, based on these initial findings, it might seem reasonable to mix Octenisept with $\mathrm{Ca}(\mathrm{OH})_{2}$ in terms of potentiating its antibacterial efficacy.

Although, MTAD appears to be an effective solution against Enterococcus faecalis, the combination of MTAD with other medicaments may reduce its antimicrobial effect on this microorganism. ${ }^{26-29}$ Our results confirm this finding, since mixing $\mathrm{Ca}(\mathrm{OH})_{2}$ with MTAD resulted in a significant decrease in the inhibition zones of Enterococcus faecalis and Enterococcus faecalis + Candida albicans, compared with those achieved by using MTAD alone. However, our findings also demonstrate that addition of $\mathrm{Ca}(\mathrm{OH})_{2}$ into MTAD may significantly increase the potential of inhibition against Candida albicans, as evidenced by the lack of antifungal effect when MTAD was used alone. Ruff et al ${ }^{30}$ have also demonstrated that the use of MTAD alone showed no antifungal effect.

The present results showed that 2\% CHX was highly effective against Enterococcus faecalis and Candida albicans (Table 3). In addition to its short-term antimicrobial effects, CHX is capable of adsorbing onto dental tissues and mucous membranes, resulting in a prolonged gradual release at therapeutic levels. ${ }^{31}$ Previous studies have demonstrated that the antimicrobial activity of CHX may decrease, when mixed with a number of substances comprising $\mathrm{Ca}(\mathrm{OH})_{2}$, urea and sulphate lauryl sodium. ${ }^{13,32,33}$ As expected, both the antimicrobial and antifungal activity of CHX decreased upon combination with $\mathrm{Ca}(\mathrm{OH})_{2}$. Other studies have observed similar antimicrobial activity of both $\mathrm{CHX}$ and $\mathrm{CHX}+\mathrm{Ca}(\mathrm{OH})_{2}$ against Enterococcus faecalis. ${ }^{6,34}$ Such differences could be attributed to many factors including differences in study design or the type of microbial strain used. It should also be cautioned that although the widely used agar diffusion method provides a practical approach in determining the antibacterial potential of endodontic irrigants, it only indicates the potential of a medication to eliminate the microorganism, and at a technical standpoint, is directly dependent on the test substance's solubility and ability to diffuse through agar. Thus results of an agar diffusion test may not express 
the actual efficacy of a medicament against tested microorganisms. 35

$\mathrm{Ca}(\mathrm{OH})_{2}$ is one of the most commonly used substances in endodontics, and its antibacterial property stems from its ability to increase the $\mathrm{pH}$ of a solution. ${ }^{6,16}$ In the present study, the antibacterial and antifungal effect of $\mathrm{Ca}(\mathrm{OH})_{2}$ was similar to that achieved by its mixture with the tested antimicrobial agents. Likewise, Delgado et $\mathrm{al}^{6}$ showed that $\mathrm{Ca}(\mathrm{OH})_{2}$ and $\mathrm{CHX}+\mathrm{Ca}(\mathrm{OH})_{2}$ had similar antimicrobial activity. However, it has also been demonstrated that CHX $+\mathrm{Ca}(\mathrm{OH})_{2}$ exerted more antimicrobial activity against Enterococcus faecalis and Candida albicans when compared with $\mathrm{Ca}(\mathrm{OH})_{2}$ alone. ${ }^{17}$

Based on the results obtained within the experimental conditions of this study, the null hypothesis should be rejected in part, owing to the differential effects of $\mathrm{Ca}(\mathrm{OH})_{2}$ addition on antimicrobial action of the tested endodontic medicaments. The present results also support the use of Octenisept as an alternative endodontic irrigant, especially in combination with $\mathrm{Ca}(\mathrm{OH})_{2}$. Likewise, mixing with $\mathrm{Ca}(\mathrm{OH})_{2}$ increased the antimicrobial spectrum of MTAD. Finally, $\mathrm{Ca}(\mathrm{OH})_{2}$ was as effective as its combination with all of the tested medicaments.

\section{REFERENCES}

1. Harrison JW. Irrigation of the root canal system. Dent Clin North Am 1984 Oct;28(4):797-808.

2. Vianna ME, Gomes BP. Efficacy of sodium hypochlorite combined with chlorhexidine against Enterococcus faecalis in vitro. Oral Surg Oral Med Oral Pathol Oral Radiol Endod 2009 Apr;107(4):585-589.

3. Rosenthal S, Spangberg L, Safavi K. Chlorhexidine substantivity in root canal dentine. Oral Surg Oral Med Oral Pathol 2004 Oct;98(4):488-492.

4. Tirali RE, Turan Y, Akal N, Karahan ZC. In vitro antimicrobial activity of several concentrations of $\mathrm{NaOCl}$ and Octenisept in elimination of endodontic pathogens. Oral Surg Oral Med Oral Pathol Oral Radiol Endod 2009 Nov;108(5):e117-e120.

5. Sathorn C, Parashos P, Messer H. Australian endodontists' perceptions of single and multiple visit root canal treatment. Int Endod J 2009 Sep;42(9):811-818.

6. Delgado RJ, Gasparoto TH, Sipert CR, Pinheiro CR, Moraes IG, Garcia RB, Bramante CM, Campanelli AP, Bernardineli N. Antimicrobial effects of calcium hydroxide and chlorhexidine on Enterococcus faecalis. J Endod 2010 Aug;36(8):1389-1393.

7. Gomes BP, Ferraz CC, Vianna ME, Berber VB, Teixeira FB, Souza-Filho FJ. In vitro antimicrobial activity of several concentrations of sodium hypochlorite and chlorhexidine gluconate in the elimination of Enterococcus faecalis. Int Endod J 2001 Sep;34(6):424-428.

8. Gomes BP, Souza SF, Ferraz CC, Teixeira FB, Zaia AA, Valdrighi L, Souza-Filho FJ. Effectiveness of $2 \%$ chlorhexidine gel and calcium hydroxide against Enteroccoccus faecalis in bovine root dentine in vitro. Int Endod J 2003 Apr;36(4): 267-275.
9. Slee AM, O’Connor JR. In vitro antiplaque activity of octenidine dihydrochloride (WIN 41464-2) against preformed plaques of selected oral plaque-forming microorganisms. Antimicrob Agents Chemother 1983 Mar;23(3):531-535.

10. Heeg P. Antisepsis of mucous membranes-current status and aspects of future development. Z Gesamte Hyg 1990 Feb;36(2):83-86.

11. Decker EM, Weiger R, Wiech I, Heide PE, Brecx M. Comparison of antiadhesive and antibacterial effects of antiseptics on Streptococcus sanguinis. Eur J Oral Sci 2003 Apr;111(2):144-148.

12. Mohammadi Z, Shahriari S. Residual antibacterial activity of chlorhexidine and MTAD in human root dentin in vitro. J Oral Sci 2008 Mar;50(1):63-67.

13. de Souza-Filho FJ, Soares Ade J, Vianna ME, Zaia AA, Ferraz $\mathrm{CC}$, Gomes BP. Antimicrobial effect and $\mathrm{pH}$ of chlorhexidine gel and calcium hydroxide alone and associated with other materials. Braz Dent J 2008;19(1):28-33.

14. Molander A, Dahlén G. Evaluation of the antibacterial potential of tetracycline or erythromycin mixed with calcium hydroxide as intracanal dressing against Enteroccus faecalis in vivo. Oral Surg Oral Med Oral Pathol Oral Radiol Endod 2003 Dec;96(6):744-750.

15. Gomes BP, Sato E, Ferraz CC, Teixeira FB, Zaia AA, SouzaFilho FJ. Evaluation of time required for recontamination of coronally sealed canals medicated with calcium hydroxide and chlorhexidine. Int Endod J 2003 Sep;36:604-609.

16. Siqueira JF Jr, Lopes HP. Mechanisms of antimicrobial activity of calcium hydroxide: a critical review. Int Endod J 1999 Sep;32(5):361-369.

17. Turk BT, Sen BH, Ozturk T. In vitro antimicrobial activity of calcium hydroxide mixed with different vehicles against Enterococcus faecalis and Candida albicans. Oral Surg Oral Med Oral Pathol Oral Radiol Endod 2009 Aug;108(2):297-301.

18. Lee HY, Andalibi A, Webster P, Moon S-K, Teufert K, Kang S-H, Li J-D, Ganz T, Lim DJ. Antimicrobial activity of innate immune molecules against Streptococcus pneumoniae, Moraxella catarrhalis and nontypeable Haemophilus influenzae. BMC Infect Dis 2004 Nov; 4:12.

19. Sathorn C, Parashos P, Messer HH. Effectiveness of singleversus multiple-visit endodontic treatment of teeth with apical periodontitis: a systematic review and meta-analysis. Int Endod J 2005 Jun;38(6):347-355.

20. Gomes BP, Lilley JD, Drucker DB. Association of endodontic symptoms and signs with particular combinations of specific bacteria. Int Endod J 1996 Mar;29(2):69-75.

21. Duggan JM, Sedgley CM. Biofilm formation of oral and endodontic Enterococcus faecalis. J Endod 2007 Jul;33(7):815818.

22. Gilbert P, Maira-Litran T, McBain AJ, Rickard AH, Whyte FW. The physiology and collective recalcitrance of microbial biofilm communities. Adv Microb Physiol 2002;46:202-256.

23. Hope CK, Garton SG, Wang Q, Burnside G, Farrelly PJ. A direct comparison between extracted tooth and filter-membrane biofilm models of endodontic irrigation using Enterococcus faecalis. Arch Microbiol 2010 Sep;192(9):775-781.

24. Oliver JD. The viable but nonculturable state in bacteria. J Microbiol 2005 Feb;43:93-100.

25. Waltimo TMT, Orstavik D, Sirén EK, Haapasalo MPP. In vitro susceptibility of Candida albicans to four disinfectants and their combinations. Int Endod J 1999 Nov;32(6):421-429. 
26. Torabinejad M, Shabahang S, Aprecio RM, Kettering JD. The antimicrobial effect of MTAD: an in vitro investigation. J Endod 2003 Jun;29(6):400-403.

27. Davis JM, Maki J, Bahcall JK. An in vitro comparison of the antimicrobial effects of various endodontic medicaments on Enterococcus faecalis. J Endod 2007 May;33(5):567-569.

28. Krause TA, Liewehr FR, Hahn CL. The antimicrobial effect of MTAD, sodium hypochlorite, doxycycline, and citric acid on Enterococcus faecalis. J Endod 2007;33(1):28-30.

29. Tay FR, Hiraishi N, Schuster GS, Pashley DH, Loushine RJ, Ounsi HF, Grandini S, Yau JY, Mazzoni A, Donnelly A. Reduction in antimicrobial substantivity of MTAD after initial sodium hypochlorite irrigation. J Endod 2006 Oct;32(10):970-975.

30. Ruff ML, McClanahan SB, Babel BS. In vitro antifungal efficacy of four irrigants as a final rinse. J Endod 2006 Apr;32(4):331333.

31. Komorowski R, Grad H, Wu XY, Friedman S. Antimicrobial substantivity of chlorhexidine treated bovine root dentin. J Endod 2000 Jun;26(6):315-317.

32. Hauman CH, Love RM. Biocompatibility of dental material used in contemporary endodontic therapy: a review. Part 1 . Intracanal drugs substances. Int Endod J 2003 Feb;36(2):75-85.

33. Haenni S, Schmidlin PR, Mueller B, Sener B, Zehnder M. Chemical and antimicrobial properties of calcium hydroxide mixed with irrigating solutions. Int Endod J 2003 Feb;36(2):100105.

34. Zerella JA, Fouad AF, Spangberg LS. Effectiveness of a calcium hydroxide and chlorhexidine digluconate mixture as disinfectant during retreatment of failed endodontic cases. Oral Surg Oral Med Oral Pathol Oral Radiol Endod 2005 Dec;100(6):756-761.

35. Mayrhofer S, Domig KJ, Mair C, Zitz U, Huys G, Kneifel W. Comparison of broth microdilution, Etest, and agar disk diffusion methods for antimicrobial susceptibility testing of Lactobacillus acidophilus group members. Appl Environ Microbiol 2008 Apr;74(12):3745-3748.

\section{ABOUT THE AUTHORS}

\section{Resmiye Ebru Tirali (Corresponding Author)}

Assistant Professor, Department of Pediatric Dentistry, Başkent University, Ankara, Turkey, e-mail: ebru_aktepe@hotmail.com

\section{Kamran Gulsahi}

Assistant Professor, Department of Endodontics, Başkent University Ankara, Turkey

\section{Sevi Burcak Cehreli}

Associate Professor, Department of Pediatric Dentistry, Başkent University, Ankara, Turkey

\section{Zeynep Ceren Karahan}

Associate Professor, Department of Medical Microbiology, Ankara University, Ankara, Turkey

\section{Emel Uzunoğlu}

Research Fellow, Department of Medical Microbiology, Ankara University, Ankara, Turkey

\section{Atilla Elhan}

Associate Professor, Department of Biostatistics, Ankara University Ankara, Turkey 